\title{
El rol de las imágenes mentales en la educación imaginativa y ecológica
}

\author{
Gillian Judson \\ Simon Fraser University \\ Traducción de María de la Luz Matte
}

\section{RESUMEN}

Este artículo explora cómo podrían contribuir las imágenes mentales evocadas mediante la palabra a mejorar el aprendizaje de contenidos en todo el currículum y cómo podrían ayudar a desarrollar en los estudiantes la comprensión ecológica: ese profundo sentido de conexión con un mundo vivo y el cuidado y la preocupación por vivir de una manera diferente en él. Pretendo explicar la importancia de abordar con mayor profundidad las imágenes mentales en los procesos de aprendizaje, tomando como referencia el trabajo de Elliot Eisner y Kieran Egan. El artículo concluye con una discusión de las implicancias pedagógicas que tiene el diseño de experiencias pedagógicas basadas en el involucramiento de estudiantes y profesores desde la creatividad con los contenidos del currículum, en la medida en que estas resultan más significativas y motivadoras para los estudiantes.

Palabras claves: imágenes mentales, compromiso emocional, imaginación comprensión ecológica, adquisición de conocimientos

Este artículo apareció originalmente en el Canadian Journal of Education / Revue canadienne de l'éducation, volumen 37, número 4, de 2014. Se agradece a la revista por la autorización para traducir y publicar el artículo. 


\title{
INTRODUCCIÓN
}

\begin{abstract}
"Me encuentro sentada bajo un sicomoro junto al arroyo Tinker. Estamos a principios de la primavera.

"He venido al arroyo - al tramo del arroyo que discurre por detrás de la casa-, a mediodía, para sentir en el aire la delicada concentración de calor, el auténtico calor del sol, y para ver cómo descienden las aguas nuevas". (Dillard, 1990, p. 129)
\end{abstract}

Estoy releyendo el libro Una temporada en Tinker Creek de Annie Dillard (1990) y, al igual que la primera vez que me encontré con este texto, estoy asombrada de cómo me siento imaginativamente transportada hacia su experiencia. Las vívidas imágenes mentales que ella utiliza evocan en mí fuertes respuestas emocionales y sensoriales. En la medida en que avanzo en la lectura, no estoy de ninguna manera cerca de Tinker Creek o del sicomoro en el cual ella se apoya, pero de hecho puedo, a través de sus palabras, sentir su corteza en mi espalda. Puedo sentir la sensación física que ella describe vívida y detalladamente. Puedo sentir el mundo en el cual estoy inmersa, más aún, puedo sentir una extraña mezcla de emociones confrontándose: ¿humildad?, ¿asombro?, ¿confusión?, ¿placer?, ¿preocupación? Así me siento súbitamente impactada por cómo pone en primer plano, a través de sus palabras, la vida y su abundancia.

Annie Dillard es una de las muchas escritoras talentosas que disfruto leer y es una experta en evocar imágenes mentales. Es una artista que usa las palabras para pintar en las mentes de sus lectores lienzos poderosos, seductores y cargados de emoción. Sus imágenes dejan en mí una profunda impresión -su significado sigue resonando en mí mucho tiempo después que he dejado el libro- y me siento impactada por la potencia de sus imágenes mentales y cómo provocan mi imaginación y sensación de asombro. 


\begin{abstract}
"Este sicomoro es antiguo; la parte más baja de la corteza está siempre grisácea debido a las crecidas que todos los años golpean su tronco. Como muchos sicomoros, este también es peculiar, muy dado a los vuelos y a las desviaciones. Su tronco se inclina hacia el arroyo formando un ángulo vertiginoso, y desde ese tronco se extiende una rama larga y delgada que se derrama sobre la orilla opuesta sin bifurcarse. El arroyo refleja la superficie moteada de esa rama, clara incluso en comparación con las nubes más altas; su imagen palidece todavía más y se estrecha a medida que atraviesa las aguas, se rompe en mil pedazos en los rápidos y se vuelve a juntar más adelante, temblorosa y jaspeada, como si hubiera un reptil primitivo y enorme por debajo de ella”. (Dillard 1990, p. 130)
\end{abstract}

\title{
EL INICIO: MI VISIÓN DE UNA PEDAGOGÍA IMAGINATIVA Y ECOLÓGICA
}

Este artículo representa el inicio de lo que espero sea una investigación más profunda y extensa sobre el rol de las imágenes mentales en una enseńanza imaginativa y ecológica. Quiero explorar cómo las imágenes mentales evocadas por medio de palabras pueden mejorar el aprendizaje de contenidos en todo el currículum y cómo podrían ayudar a desarrollar en los estudiantes la comprensión ecológica: ese profundo sentido de conexión con un mundo vivo y el cuidado y la preocupación por vivir de una manera diferente en él. Comienzo por entregar los fundamentos de este estudio para incorporar con mayor profundidad las imágenes mentales en el proceso de enseńanza. Tanto Elliot Eisner (2011) como Kieran Egan (1979, 1997, 2005) dan testimonio de la potencia de estas y su inmenso valor para el aprendizaje. Ambos también reconocen su ausencia en la mayoría de las salas de clases.

Mi objetivo es mostrar lo que es posible para la enseñanza si tomamos en serio la noción de Eisner (2011) en cuanto que la imagen es el núcleo de la educación. Lo que planteo al final de este artículo es 
una síntesis de las implicancias pedagógicas y un bosquejo del tipo de pedagogía que se requiere para situar las imágenes en el centro de la educación. Una pedagogía basada o focalizada en imágenes no encaja bien en los modelos educacionales basados en los objetivos con los cuales reciben su formación la mayoría de los profesores, por lo que intentaré evocar una nueva imagen: a través de este nebuloso modelo de nuestro currículo de enseñanza brilla una nueva posibilidad para lograr experiencias educacionales más significativas y motivadoras, basadas en el uso de la imaginación de estudiantes y profesores para conectarse con los contenidos del currículo. Aunque el desarrollo en detalle de una pedagogía basada en el uso de la imagen es tema para otro texto, aquí bosquejo las bases de lo que se necesita para lograr que los alumnos aprendan usando las imágenes y el modo cómo podemos cultivar en los estudiantes, desde tempranas edades, la agudeza emocional y mental que se requiere para experimentar y describir de manera sugerente las maravillas del mundo que los rodea.

A lo largo del artículo utilizo ejemplos de las inspiradoras y evocadoras palabras de Annie Dillard. Espero que al incluir su voz junto a la mía, mientras escribo un artículo de alguna manera atípico, pueda darles a ustedes la oportunidad de experimentar el poder de las imágenes para involucrar al cuerpo y evocar una sensación de asombro. Los invito a conocer sus palabras y a permitir que las imágenes surjan en sus mentes.

\section{POR QUÉ LAS IMÁGENES MENTALES SON IMPORTANTES: PERSPECTIVAS DE ELLIOT EISNER Y KIERAN EGAN}

Elliot Eisner (2011) coloca las imágenes en el centro mismo de la educación. Argumenta que los estudiantes simplemente no pueden aprender a menos que las imágenes estén ligadas al contenido que enseñamos: "Si quieres asegurar un aprendizaje verbal sin sentido en tu clase, asegúrate de que los nińos no tengan imágenes para lo 
que estás tratando de enseñarles" (p. 31). Señala cómo las imágenes pueden ser empleadas para representar ideas muy complejas y, a través de sus características únicas, pueden evocar significados que trascienden el lenguaje. Las imágenes, para los profesores, son el medio a través del cual podemos captar significados que nuestras palabras por sí solas no pueden expresar.

Los grandes maestros lo saben desde hace mucho tiempo: las imágenes evocan un significado complejo y pueden enriquecer ese significado poniendo de relieve aquello que es inexpresable en las palabras. Eisner da un ejemplo de cómo Sócrates trató de evocar el significado de la naturaleza del conocimiento en La República con la analogía de una línea que describe las diferencias en la claridad del conocimiento, desde la conjetura y la creencia hasta la comprensión. Basándose en su evaluación del conocimiento de Glaucón, Sócrates se dio cuenta de que no había tenido mucho éxito en la enseñanza de este concepto, por lo que a continuación evocó el significado a través de una imagen. Es probable que estén familiarizados con la imagen de Platón de la caverna en el Libro 7 de La República (Ferrari, 2000). Para la mayoría de la gente, y para Glaucón, la imagen de la caverna evoca más significado que la analogía de la línea. La imagen de la caverna nos atrae somáticamente: "vemos", de alguna manera, las sombras danzando; sentimos, de repente, la sensación de incertidumbre ante lo que estamos viendo; podemos tener el impulso de darnos la vuelta y, en nuestra imaginación, sentir nuestra incapacidad para hacerlo, restringidos por las cadenas que nos sujetan. Por lo tanto, las imágenes evocan nuestros sentidos y, lo que es más importante, nuestras emociones; evocan un significado que trasciende las palabras (Eisner, 2011).

Kieran Egan, como Eisner, reconoce la fuerza pedagógica de las imágenes $(1979,1997,2005)$. Egan identifica las imágenes mentales evocadas a partir de las palabras como una de las herramientas de aprendizaje más poderosas -o lo que él llama "herramientas cognitivas"- que los seres humanos tienen para mediar y dar sentido a sus experiencias. Por muy pequeñas que sean, las imágenes creadas en 
nuestras mentes tienen un componente afectivo; evocan la imaginación humana. Una imagen poderosa entrelaza el contenido curricular con la emoción humana y, posiblemente, con una experiencia física o somática. Como bien sabían los bardos, evocar imágenes mentales con palabras era una forma efectiva de hacer que el contenido de las historias fuera significativo para los oyentes. Desde que los seres humanos comenzaron a hablar con fluidez $-\mathrm{y}$ tuvieron que hacer frente al desafío de mantener la cohesión dentro de grupos sociales más grandes-, la imagen mental vívida ha tenido un valor inmenso como herramienta de "socialización" y aprendizaje. Integra el conocimiento en una forma memorable; vincula las respuestas emocionales con su contenido. Egan (1997) destaca que la imagen vívida que se evoca a partir de las palabras es una de las primeras herramientas de pensamiento que desarrollamos cuando aprendemos a hablar un idioma oral, pero que también permanece con nosotros a lo largo de nuestra vida.

Así que, tanto para niños como adultos, desde hace 2.500 años hasta el presente, las palabras pueden ser empleadas ingeniosamente para estimular imágenes poderosas y memorables en la mente. Desafortunadamente, tendemos a ignorar el valor pedagógico de la imagen mental en nuestra metodología de enseñanza y rara vez, si es que lo hacemos, aprendemos acerca de su poder para el aprendizaje en la formación de profesores.

"Estoy sentada bajo un sicomoro: soy un caparazón blando y descascarillado, vulnerable al más mínimo soplo del viento o azote de la arena. El presente de nuestra vida parece distinto debajo de los árboles. Los árboles ejercen su dominio. Los árboles no acumulan vida, sino madera seca, como una cota de malla cada vez más espesa. De hecho, sus posibilidades de salir adelante aumentan con la edad". (Dillard, 1990, p. 138) 


\section{IMÁGENES MENTALES: ALGUNAS CARACTERÍSTICAS PEDAGÓGICAS}

Eisner (2011) señala las características de las imágenes que apoyan su valor en el aula. Estas incluyen: a) su naturaleza multisensorial, b) su conexión con las emociones humanas y la imaginación, c) su capacidad para evocar múltiples tipos de relaciones, yd) sus diferentes formas (lo que él llama la imagen recordada y la imagen imaginativa).

\section{Las imágenes son multisensoriales}

Eisner (2011) describe las imágenes mentales como multimodales o multisensoriales; las imágenes pueden evocar todos los sentidos del cuerpo:

Las imágenes pueden formarse en cualquier modalidad sensorial. Tendemos a pensar que las imágenes son visuales, pero las imágenes también pueden ser auditivas. Pueden ser táctiles. Pueden ser olfativas. De hecho, las imágenes pueden adaptarse a cualquier modalidad sensorial que opere en un individuo. (pp. 30-31)

Como sugiere Eisner, el lenguaje que usamos para hablar de las imágenes tiende a llevarnos a pensar en ellas como algo visual. Su argumento es que su poder educativo se relaciona con la forma en que todo el cuerpo puede involucrarse en una imagen evocadora creada en la mente. ¿Ha experimentado alguna vez ese repentino cambio en el tiempo y el espacio cuando un olor o sonido en particular lo transportó imaginativamente a un lugar y tiempo diferentes? Una imagen poderosa puede generar múltiples percepciones corporales que se vinculan al proceso de aprendizaje. Podemos aprender, a través de las imágenes, de modo que se utilicen las herramientas de aprendizaje del cuerpo y contribuyan al significado del conocimiento para los estudiantes. 


\section{Las imágenes evocan la emoción y la imaginación}

Eisner (2011) también observó que las imágenes a menudo van de la mano con otras herramientas de la imaginación. Así, por ejemplo, el contenido curricular configurado de manera que evoque la emoción y la imaginación (por ejemplo, la forma del cuento) también tiende a evocar imágenes en la mente. La imagen, la forma del cuento y otras herramientas de la imaginación son poderosas herramientas para la cohesión e identidad culturales; son "una forma de moneda social" que hacen que el conocimiento tenga sentido y ayudan a transmitir el conocimiento cultural (pág. 30). Egan está de acuerdo. Su teoría de la educación imaginativa ${ }^{1}$ (IE) proporciona un marco teórico y una guía práctica para emplear una infinidad de herramientas de la imaginación. Mediante el empleo de las imágenes mentales y otras herramientas de aprendizaje o "herramientas cognitivas" -herramientas como la narración, las asociaciones con héroes y una sensación de asombro- vinculamos el conocimiento del contenido con la emoción y la imaginación. El contenido se vuelve memorable para los estudiantes; el significado se recuerda mucho tiempo después de que haya terminado la clase.

\section{Las imágenes evocan relaciones}

Eisner (2011) señala que las imágenes son diacrónicas y sincrónicas. Esto es, en palabras de Eisner, "simplemente una forma elegante de decir que imágenes como la bandera ofrecen una presentación inmediata de una configuración significativa" (p. 32). Si eres parte de la cultura en la que esa "imagen" tiene significado, entonces puedes "captarlo de inmediato" cuando ves una imagen (p. 32).

Las imágenes son diacrónicas porque expresan el significado a lo largo del tiempo. Evocan un significado que es dinámico, que se desarrolla con el tiempo y a través de la experiencia; pueden ser recordadas, configuradas por nuevos conocimientos y emociones. Las imágenes también son sincrónicas, ya que pueden evocar múltiples relaciones simultáneamente, a menudo aclarando relaciones epistemológicas 
que no se capturan tan fácilmente con otros medios (Eisner, 2011). Eisner (2011) sugiere que el poder de una imagen para "capturar" múltiples relaciones y significados simultáneamente explica que el "mapa conceptual" sea una de las herramientas de enseñanza preferidas por muchos educadores.

\section{Las imágenes son recordadas y creadas}

Por último, Eisner (2011) menciona al menos dos tipos de imágenes: imágenes recordadas e imágenes imaginativas. Las primeras son las que evocamos desde la memoria (por ejemplo, un avión), y las segundas son las que creamos combinando conocimientos (por ejemplo, una forma completamente nueva de transporte: ¿Cómo podría ser? ¿Qué combustible usaría? ¿Qué tamaño tendría?). Queremos que nuestros estudiantes sean capaces de recordar una imagen vívida que les proporcionamos para enseñar un concepto (por ejemplo, una flor que se abre y florece), pero también queremos que los estudiantes sean capaces de crear fácil y eficazmente sus propias imágenes que combinen sus propias interpretaciones de maneras nuevas y generativas.

"Estoy sentada bajo un sicomoro junto al Tinker. Estoy aquí realmente, viva sobre la tierra intrincada que hay bajo los árboles. Pero, por debajo de mí, justo debajo del peso de mi cuerpo sobre la hierba, hay otras criaturas igual de reales que yo, para las cuales también este momento y este árbol son 'eso'. A solo un centímetro de profundidad desde la superficie del suelo, por debajo de la palma de mi mano, el mundo se retuerce. A un centímetro de profundidad, los biólogos encontraron una media de 1.356 criaturas vivas en un área de diez centímetros cuadrados, incluyendo 865 ácaros, 265 colémbolos, 22 milpiés, 19 escarabajos adultos y criaturas de otras 12 especies distintas. Una estimación de la población microscópica determinó que podía haber más de dos mil millones de bacterias y muchos millones de hongos, protozoos y algas en una sola cucharadita de tierra de bosque". (Dillard, 1990, p. 142) 


\section{La dimensión ecológica: las imágenes apoyan la comprensión de la otredady la interconexión}

En esta sección espero aclarar el valor de las imágenes para la comprensión ecológica. Para ello, comenzaré detallando un poco más las características de las imágenes que apoyan el aprendizaje en general. La naturaleza multisensorial de las imágenes, por ejemplo, es algo que puede apoyar un significado más rico y variado en todas las áreas del plan de estudios de los estudiantes. Pero la evocación del cuerpo es particularmente poderosa para comprender e involucrarse somáticamente en el mundo. Las imágenes que evocan los sentidos nos ayudan a experimentar el mundo de manera más holística; podemos tener más conciencia de cómo nuestros cuerpos están conectados con nuestro entorno y tenemos más probabilidad de sentir una sensación de inmersión o integración en el mundo.

Las imágenes también evocan, como señalaba Eisner (2011), la emoción y la imaginación. Es esta dimensión imaginativa la que puede promover un sentido de la otredad. Egan (1997) indica, por ejemplo, cómo las imágenes mentales pueden permitir a los estudiantes experimentar imaginativamente otra perspectiva:

Las imágenes nos permiten, en un sentido limitado pero muy real, ampliar nuestra comprensión del mundo. Las imágenes afectivas no necesitan reducir el contenido que se enseña; más bien, son un medio para que el niño lo 'incorpore'. Esto les ayuda a ver que las matemáticas, la historia y la ciencia no están hechos de conocimiento alienígena, algo que está ahí fuera, separado de ellos. Al captar el conocimiento imaginativamente, los nińos lo hacen, recíprocamente, formar parte de sí mismos. De este modo, los nińos descubren que son seres matemáticos, históricos y científicos. (p. 62)

El ejemplo de la flor de Egan (1997) ilustra cómo las imágenes mentales pueden sustentar el compromiso imaginativo y emocional de los estudiantes con el mundo natural: 
Cuando se enseña sobre las flores, uno podría imaginarlas emergiendo de la fría tierra, empujando hacia la luz, estallando con una especie de éxtasis en el aire más tibio, girando con pasión hacia el sol, sintiendo el torrente de savia, y luego experimentando el horror del frío que regresa, y marchitándose de nuevo bajo tierra. (pp. 61-62)

A través de la personificación dramática del contenido, los estudiantes pueden asumir, en un sentido simbólico, otra perspectiva. Pueden identificarse con algún aspecto del mundo natural, ya que simbólicamente se "convierten" en él. Los ecologistas radicales (véase, por ejemplo, Drengson y Inoue, 1995; Fox, 1990; Naess, 1988) describen la "identificación" como un proceso en el que se experimenta un sentido de comunidad con otra entidad (Fox, 1990, p. 249). Tengo la convicción de que las imágenes mentales (en combinación con las oportunidades de educación experiencial y el desarrollo sensorial) pueden sustentar el proceso de "identificación" descrito en la literatura de ecología radical. Mediante el uso de imágenes no solo vinculamos el conocimiento con una imagen mental vívida evocada a través de las palabras y, por lo tanto, lo hacemos más memorable aumentando su significado emocional, sino que facilitamos a los estudiantes la capacidad de presenciar y experimentar la otredad.

"Las crisálidas de las mariposas también viven aquí, plegadas, rígidas, durmiendo sin soñar. Podría incluir a todas esas criaturas en este momento, es lo mejor que puedo hacer. Que yo las ignore no las va a despojar de su realidad, y al aceptarlas en mi conciencia, pueden aumentarla, pueden añadir su conciencia a mi conciencia humana, y generar una vibración, como las ondas que produce una rata almizclera al golpear el agua cuando se sumerge, en este momento particular, y desde este árbol concreto”. (Dillard, 1990, p. 142)

El argumento de Eisner (2011) de que las imágenes evocan relaciones a lo largo del tiempo y el espacio es importante. Desde una perspectiva ecológica, vemos cómo las imágenes mentales vívidas pueden sustentar el sentido de relación de los estudiantes. Es decir, las imágenes pueden llevar a los estudiantes a pensar y sentir múltiples relaciones 
a la vez, incluyendo la de su propia participación en el mundo. Las imágenes mentales pueden capturar en el tiempo y el espacio múltiples niveles de relación entre el estudiante y el tema, el tema y el lugar, el estudiante y el lugar. A través de las imágenes podemos profundizar en las relaciones individuales, experimentándolas de la forma más vívida y somática posible, pero también podemos dar un paso atrás para "observar" cómo estamos involucrados en una red más amplia de relaciones.

\section{IMÁGENES MENTALES EN EL NÚCLEO: IMPLICACIONES PEDAGÓGICAS}

Situar las imágenes en el centro de la enseñanza tiene al menos cuatro implicaciones pedagógicas. En primer lugar, la enseńanza y el aprendizaje centrados en las imágenes serán más holísticos. Dada la naturaleza multisensorial de las imágenes, su uso en las aulas conducirá a un involucramiento más frecuente del cuerpo en el aprendizaje. Tendremos que reconocer que los seres humanos son seres imaginativos que perciben, sienten y piensan simultáneamente; somos, como lo denomina David Kresch, "perfinkers"1 (perception-feeling-thinking) en contraposición a simples pensadores (como se cita en Egan, 2005, p. 8). Nuestros cuerpos y mentes siempre trabajan juntos en la creación de significado. Con la imaginería como herramienta, podemos crear experiencias de aprendizaje para los estudiantes que reconozcan esta importante dimensión de la comprensión humana.

En segundo lugar, un enfoque pedagógico que apoye el uso amplio de la imaginería trabajará en conjunto con otras herramientas de la imaginación. Una pedagogía centrada en la imagen es, por lo tanto, una pedagogía centrada en la imaginación. Los contenidos curriculares se convierten en fuentes de compromiso emocional de los profesores. Se convierten en los objetivos de nuestra evocación de imágenes y de

1 Se decidió no intentar traducir el neologismo. 
nuestra creación de imágenes. La enseñanza imaginativa requiere una conexión emocional entre un profesor y un tema. Para saber cómo involucrar imaginativamente a sus estudiantes con un tema, los profesores deben involucrarse imaginativamente ellos mismos. Esto da un giro a la idea de crear "una sensación de asombro" en el aula. De hecho, lo que sugiere es que los profesores empiecen a planear su enseñanza buscando en un tema lo que evoque su propia sensación de asombro. Esta es la conexión emocional que luego permeará toda la planificación posterior de la enseńanza. Esta es a menudo la fuente de la imagen central que el profesor querrá evocar sobre un tema; es la visión emocional e imaginativa que inspirará la forma en que los profesores den forma a su enseñanza.

Desde aquí, en un aula centrada en la imagen, los maestros enseñan de manera que continúan involucrando emocional e imaginativamente a los estudiantes en el aprendizaje. La imagen, como sabemos, va de la mano con otras herramientas de la imaginación y es enriquecida -y enriquece- a esas otras herramientas. Por lo tanto, la enseńanza en el aula a menudo utilizará las herramientas de la lengua oral, aquellas herramientas que los bardos utilizaron hace mucho tiempo, y aquellas que nuestros estudiantes ya utilizan hoy en día para dar sentido al mundo que les rodea. Estas incluyen la forma del cuento, las oposiciones abstractas y afectivas, el humor, el ritmo y el patrón, y el sentido del misterio. Un primer requisito, para la enseńanza centrada en la imagen, entonces, es que el profesor sienta algo por el tema. Por muy ingeniosamente que se identifiquen los objetivos y se configure la enseñanza, sin la conexión emocional entre el profesor, el estudiante y el tema, el resultado probable será la falta de compromiso del alumno, el aburrimiento y un aprendizaje inconsistente.

"Debajo de mi columna vertebral, las raíces del sicomoro absorben sales disueltas. Los extremos de las raíces empujan y se retuercen entre las partículas de tierra mientras exploran minuciosamente; de sus tejidos errantes y expansivos brotan minúsculos pelos absorbentes, traslúcidos y huecos que se adhieren a las partículas de tierra para poder impregnarse. Estos arroyuelos corren profundos y en silencio; 
toda la tierra tiembla, escindida y agrietada, forzada y drenada. Me pregunto qué les sucederá a los sistemas radiculares cuando los árboles mueren. ¿Morirán de inanición esas redes extensas y ciegas en medio de la abundancia y se desecarán enganchadas a las motas de tierra?” (Dillard, 1990, pp. 143-144)

En tercer lugar, la naturaleza relacional de las imágenes requerirá un replanteamiento de la naturaleza del conocimiento y la comprensión. Se nos recuerda a través de la condición diacrónica de las imágenes que la comprensión -el aprendizaje y el significado-son dinámicos. Si pensamos en el conocimiento como "estático" en la mente-como una especie de archivo insertado en distintos compartimentos-, entonces ignoramos su dependencia de la emoción y de la experiencia humanas. Si pensamos en el significado a través de la imagen, vemos que la mente produce significado solo cuando se liga a la emoción, y ese significado permanece, cambia y evoluciona con nuevas experiencias y en el contexto de la emoción humana. Nuestras imágenes cambian y se transforman, volviéndose significativas de diferentes maneras a lo largo del tiempo y de la experiencia. De este modo, las imágenes están estrechamente conectadas con la evocación de la emoción humana o lo que Egan (1997) llama la "humanización del significado". Egan (1997) sostiene que el conocimiento es significativo, es decir, su importancia puede ser comprendida por nosotros solo en el contexto de la emoción humana. Este es el plano en el cual puede cobrar vida en nuestras mentes. Por lo tanto, al enseñar, las imágenes mentales que evocamos para expresar el significado emocional de lo que enseñamos incluirá la dimensión humana; las esperanzas, los miedos y las pasiones de los involucrados en el tema.

En cuarto y último lugar, Eisner señaló que nosotros recreamos y creamos imágenes. Una implicación inmediata de este aspecto de la imaginería es que los estudiantes necesitan saber mucho para poder recordar y crear sus propias imágenes; para ser más imaginativos, los estudiantes necesitan saber más sobre el mundo. Egan (1997) ha sostenido a menudo que la educación que fomenta la imaginación debe contar con un abundante contenido, que solo podemos imaginar 
con el conocimiento que ya tenemos. Al igual que Egan, Eisner (2011) argumenta que necesitamos conocimiento para recordar imágenes y crear las nuestras. También sugiere que el papel de la educación es traficar con imágenes: "La educación puede ser considerada, al menos en parte, como un proceso de expansión de nuestro almacén de imágenes, y ayudar a los estudiantes a hacer conexiones entre sus contenidos" (p. 32). Eisner advierte que no está sugiriendo alimentar a los estudiantes con flujos de imágenes estáticas o que las imágenes singulares jamás podrían capturan toda la riqueza de significado que es posible con los contenidos curriculares, pero indica que hay ventajas pedagógicas si se dispone de un amplio stock de imágenes para lograr la creación de significado. Nuestras imágenes reflejan significados ligados a la emoción humana; son significativas y pueden expresar una amplia gama de ideas. Eisner también señala, sin embargo, que los profesores deben tener las habilidades para hacer públicas las imágenes mentales si van a emplearlas en la enseñanza:

"La expresión o representación pública de una imagen está influenciada por el grado en que somos capaces de observar y por lo que somos capaces de representar. El énfasis que quiero dejarles con respecto a esa idea es que la articulación de una imagen -en algún medio público-requiere ciertas habilidades. Cuanto mejor sea el desarrollo de esas habilidades, más refinadas serán, cuanto más sofisticadas sean, mayor será la probabilidad de que las imágenes puedan ser representadas de manera pública”. (p. 31)

El argumento de Eisner (2011) es crucial; las imágenes que los profesores desean evocar en la enseñanza para expresar el significado de los temas curriculares serán evocadoras para los estudiantes solo si pueden darles vida, si pueden usar el tipo de lenguaje que hace surgir el asombro en la experiencia. Este es el tipo de lenguaje rico que vemos con los "grandes" como Annie Dillard. No estoy sugiriendo que solo unos pocos escritores dotados puedan usar imágenes en la enseñanza, sino más bien que los maestros deben trabajar en la evocación de esas imágenes en términos que probablemente sean mucho más vívidos y 
detallados que los que típicamente usarían para describir el mundo que los rodea. Necesitan aprender a evocar imágenes en formas que despierten los sentidos del cuerpo. También, deben ser efectivos, como lo hace Dillard, buscando agregar un sentido inusual, de modo que algo ordinario insinúe lo extraordinario.

Las evocadoras imágenes de Dillard también demuestran su afiliación a un determinado lugar; expresa una profunda conexión con la naturaleza que ha desarrollado a lo largo del tiempo y la experiencia. Tanto los profesores como los estudiantes pueden conectarse con el mundo natural a través de la educación. Podemos ofrecer a los estudiantes oportunidades para experimentar somáticamente el mundo natural que los rodea y, por lo tanto, apoyar su desarrollo de conexiones emocionales y el conocimiento de sus contextos naturales locales (Judson, 2010, 2014). Los maestros pueden hacer lo mismo eficazmente.

"Las lombrices, en pasmosas procesiones, van dando tumbos por la grava que hay bajo nuestros pies, engullendo hojas caídas y expulsando toneladas de humus. Los topos cavan complejas redes de túneles; suele haber tantos junto al arroyo que cuando vengo por aquí me hundo con cada paso". (Dillard, 1990, p. 142)

Así, en una pedagogía centrada en la imagen, tanto los estudiantes como los profesores desarrollarán un rico vocabulario sobre todos los temas que están aprendiendo. Pueden tener "colecciones" de lenguaje exótico, palabras favoritas, sinónimos y antónimos.

Los profesores construirán su "almacén" de imágenes, ya sea solos o en colaboración con otros profesores y sus estudiantes. Los estudiantes tendrán oportunidades para crear y expresar sus propias imágenes mentales vinculadas a los contenidos curriculares. Al mismo tiempo, para apoyar la comprensión ecológica los estudiantes tendrán oportunidades de desarrollar la dimensión somática, basada en el cuerpo, en el mundo que los rodea. Se les alentará a expresar mediante un lenguaje evocador el modo en que experimentan el mundo a través de sus cuerpos. Se les puede invitar a visitar o volver 
a visitar determinados lugares del mundo natural que les rodea, ya sea alguna zona del patio de recreo, en el establecimiento escolar, o una plaza local. Las oportunidades para el compromiso somático y la expresión creativa serán aspectos rutinarios de todas las áreas curriculares si reconocemos la imagen en el centro de la educación.

No creo que los profesores puedan o deban hacer solos este trabajo. Por medio de la colaboración con sus pares pueden obtener apoyo para evocar esas ideas verbalmente. A través de la colaboración también pueden construir colecciones de imágenes, ampliando el "almacén de imágenes", como sugiere Eisner (2011). Los profesores pueden desarrollar y almacenar en forma colaborativa textos que evoquen imágenes vinculadas a diferentes contenidos curriculares. Nuestros bancos de recursos de aprendizaje contienen ejercicios, ideas de proyectos y muchas otras estrategias; pero no tengo conocimiento de ningún depósito de imágenes mentales.

Además de desarrollar sus propias habilidades, los profesores trabajarán con los estudiantes. Si el objetivo es convertir las imágenes en el núcleo de las aulas, entonces queremos que los estudiantes sean capaces de expresar -hacer públicas- sus propias imágenes. Si los profesores prestan la debida atención al desarrollo del vocabulario de los estudiantes, proporcionándoles léxico matizado y amplio, y dedicando tiempo y atención a brindarles oportunidades para la expresión creativa, los estudiantes pueden, sin duda, hacer públicas sus imágenes. Ese será el momento cuando podamos explorar el valor de la imagen no solo para el aprendizaje, sino también para la evaluación de los estudiantes y la evaluación de los contenidos curriculares.

"Por debajo de todas las coníferas del mundo -debajo del cedro que hay detrás de mí, en la orilla del arroyo- un manto de hongos envuelve la tierra formando una trama de filamentos ciegos y frágiles de un blanco palidísimo y desleído. Desde una punta de una raíz a otra, desde un pelo absorbente a otro, estos filamentos serpentean y se enrollan...” (Dillard, 1990, p. 144) 
En resumen, vemos que tomar en serio las imágenes como herramienta pedagógica requiere que tanto los profesores como los estudiantes aprendan habilidades particulares. Eisner (2011) argumenta que hay muchas palabras y significados que tratamos de evocar que no tienen imágenes. Del mismo modo, hay muchos temas curriculares que enseñamos que pueden no tener una imagen inmediata que podamos evocar y hay muchos conceptos sobre los que podríamos pedir a los estudiantes que aprendan $-\mathrm{y}$ recuerden- que no tienen una imagen. Sugiere formas de aumentar el "almacén de imágenes" de los estudiantes y formas de ayudarlos a hacer conexiones entre sus contenidos (p. 32). Podemos enseńar de una manera que motive a los estudiantes a (a) recordar imágenes, (b) crear sus propias imágenes, y lo que es más importante, (c) desarrollar las habilidades para expresar o hacer públicas las imágenes.

"Pero los insectos y lombrices, los topos, las ratas almizcleras, las raíces y los filamentos micóticos no lo son todo. Un movimiento aún más delicado, una pavana, se está llevando a cabo ahora mismo por debajo de mí. Las ninfas de las cigarras están vivas. Se ven sus pieles escindidas, de un par de centímetros de longitud, marrones y traslúcidas, arqueadas y segmentadas como una gamba, pegadas al tronco de los árboles. Y de vez en cuando se ven cigarras adultas, grandes y robustas, con los cuerpos brillantes, negros y verdes, con las alas transparentes y nervadas plegadas al dorso y la mirada artificial de sus ojos color rojo intenso. Pero nunca ves a las ninfas vivas. Están bajo tierra, aferradas a las raíces y sorbiendo la dulce savia de los árboles". (Dillard, 1990, pp. 144-145)

\section{REFLEXIONES FINALES}

Las imágenes pueden simultáneamente atraernos hacia el más pequeño de los espacios y abrir nuestra conciencia. Las imágenes pueden extraer las particularidades de un lugar, trayendo a nuestra 
conciencia la singularidad de nuestro involucramiento en el mundo. Las imágenes pueden evocar el compromiso sensorial de los estudiantes, enriqueciendo aún más el aprendizaje al aprovechar la participación sensorial del cuerpo en la experiencia. Las imágenes en el aula imaginativa y ecológica ayudan a los estudiantes a pensar; ayudan a los estudiantes a hacer y expresar su comprensión de diversos temas curriculares.

Como parte de una amplia y rica pedagogía imaginativa, en el aula enfocada en la imagen ofrecemos a los estudiantes la oportunidad de una expresión creativa de su mundo. La imagen es, por lo tanto, una herramienta que contribuye al tipo de pedagogía transformadora que requiere el cultivo de la comprensión ecológica. Mediante la palabra hablada, los estudiantes pueden evocar su sentido de estar en un mundo relacional; son hablantes, lectores y escritores de significado. Sus palabras evocan y crean sus mundos y, por tanto, están intrincadamente entretejidas con la forma en que entienden el mundo y sus posibilidades. Sus imágenes son dinámicas; revelan un mundo que siempre y para siempre están releyendo, reescribiendo y renovando a medida que lo experimentan.

Dillard se esfuerza mucho para "ver" el mundo de manera diferente. Vive cuidadosa y deliberadamente con un alto grado de alerta y documenta sus experiencias con detalles intrincados. A través de sus palabras compartimos su experiencia de inmersión. Sus palabras nos transportan a un espacio-tiempo y una experiencia diferentes, en los que podemos sentir, de una manera menor pero memorable, la inmensidad del universo que ella está experimentando. Es posible que al abordar las imágenes en una pedagogía centrada en la imaginación podamos desarrollar este tipo de alerta, lo que Dillard describe como una forma diferente de "ver", entre nuestros estudiantes. Al cultivar la alerta emocional y somática de los estudiantes, les proporcionamos una rica experiencia para que puedan generar sus propias imágenes mentales. Junto con oportunidades de aprendizaje que les proporcionen un vocabulario sofisticado y sensible, nuestros estudiantes podrán convertirse en rapsodas, es decir, narradores de historias, ya que sus 
palabras sobre el lugar y su inmersión en él evocarán vívidas imágenes mentales. Sus palabras podrán resonar con significado mucho tiempo después de que haya terminado la clase.

\footnotetext{
"Y por debajo de las cigarras, a mayor profundidad que la raíz primaria más larga, entre las rocas redondeadas y negras y las láminas de arenisca oblicuas de la tierra, más abajo aún, se deslizan las aguas subterráneas. Estas aguas se filtran y se escurren, a través del suelo, cada vez más hondo, goteando paulatinamente, avanzando a razón de un kilómetro y medio al año. ¡Menuda lucha la del agua! Un continuo tira y afloja en todas direcciones. El mundo es una batalla salvaje por debajo de la hierba: la tierra debe ser removida". (Dillard, 1990, pp. 145-146)
}

\section{REFERENCIAS}

Dillard, A. (1990). Pilgrim at Tinker Creek. In Dillard, A., Three by Annie Dillard: Pilgrim at Tinker Creek, An American childhood, The writing life (pp. 1-260). Harper Perennial.

Drengson, A. \& Inoue, Y. (1995). The deep ecology movement: An introductory anthology. North Atlantic Books.

Egan, K. (1979). Educational development. Oxford University Press. Egan, K. (1997). Educated mind: How cognitive tools shape our understanding. University of Chicago Press.

Egan, K. (2005). An imaginative approach to teaching. Jossey-Bass. Eisner, E. (2011). Images at the core of education. The Journal of the Imagination in Language Learning, 9, 30-34.

Ferrari, G. R. F. (Ed.). (2000). Plato. The Republic. T. Griffith (Trans.). Cambridge University Press.

Fox, W. (1990). Toward a transpersonal ecology: Developing new foundations for environmentalism. Shambhala Publications. 
Judson, G. (2010). A new approach to ecological education: Engaging students' imaginations in their world. Peter Lang.

Judson, G. (2014). Engaging imagination in ecological education: Practical strategies for teaching. Pacific Educational Press.

Naess, A. (1988). Deep ecology and ultimate premises. Ecologist, 18(4-5), 128-131. 